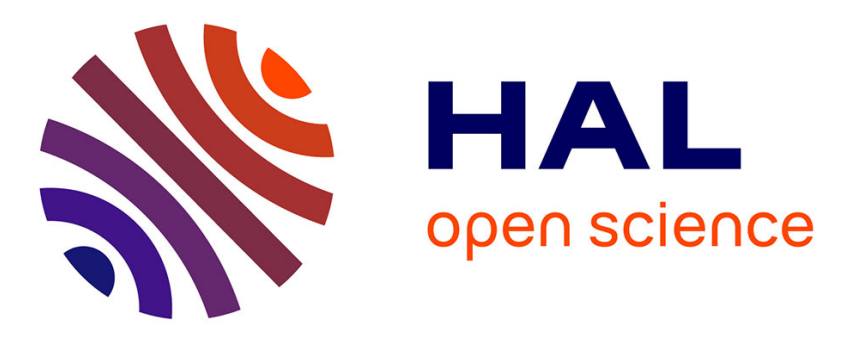

\title{
High Stocking Density Controls Phillyrea Angustifolia in Mediterranean Grasslands
}

François Mesléard, Nicole Yavercovski, Gaétan Lefebvre, Loic Willm, Anne Bonis

\section{> To cite this version:}

François Mesléard, Nicole Yavercovski, Gaétan Lefebvre, Loic Willm, Anne Bonis. High Stocking Density Controls Phillyrea Angustifolia in Mediterranean Grasslands. Environmental Management, 2017, 59 (3), pp.455-463. 10.1007/s00267-016-0808-x . hal-01483990

HAL Id: hal-01483990 https://hal-univ-rennes1.archives-ouvertes.fr/hal-01483990

Submitted on 18 Jul 2017

HAL is a multi-disciplinary open access archive for the deposit and dissemination of scientific research documents, whether they are published or not. The documents may come from teaching and research institutions in France or abroad, or from public or private research centers.
L'archive ouverte pluridisciplinaire HAL, est destinée au dépôt et à la diffusion de documents scientifiques de niveau recherche, publiés ou non, émanant des établissements d'enseignement et de recherche français ou étrangers, des laboratoires publics ou privés. 


\title{
High Stocking Density Controls Phillyrea Angustifolia in Mediterranean Grassland
}

\author{
François Mesléard ${ }^{1}$ Nicole Yavercovski ${ }^{1}$ Gaétan Lefebvre ${ }^{1}$ Loic Willm ${ }^{1}$ Anne Bonis ${ }^{3}$
}

\begin{abstract}
Extensive grazing applied in the form of low instantaneous pressure over a long period is a widespread management practice in protected areas. However this kind of stocking method does not always achieve the expected results, in particular because it fails to limit colonization by woody plants. This is the case in the relict xero-halophytic grasslands of the northern Mediterranean coastal region, subjected to widespread colonization by the shrub Phillyrea angustifolia despite the presence of extensive grazing. In this study, we investigated, for an equal annual stocking rate, the respective impact of high stocking density applied over a short period (mob grazing) and low stocking density applied over a long period on both $P$. angustifolia
\end{abstract}

and herbaceous cover, using an in situ experimental design run for 7 years. Only mob grazing was effective both in controlling the establishment and increasing the mortality of $P$. angustifolia individuals. We did not find any difference after the 7 years of experimentation between the two stocking methods with regard to the herbaceous community parameters tested: species richness, diversity, evenness, contribution of annual characteristic species. By contrast, the exclusion of domestic grazing led to a strong reduction of these values. The use of mob grazing may be well suited for meeting conservation goals such as maintaining open habitats in these grasslands

Keywords Extensive grazing,Mediterranean grassland, Mob stocking, Phillyrea angustifolia, Stocking density, Woody colonization

François Mesléard: mesleard@tourduvalat.org francois.mesleard@univ-avignon.fr

\footnotetext{
${ }^{1}$ Institut de recherche de la Tour du Valat Le Sambuc Arles 13200 France

${ }^{2}$ Institut Méditerranéen de Biodiversité et d'Ecologie (IMBE) UMR CNRS IRD, Avignon Université, Aix Marseille Université 337 chemin des Meinajariés, IUT Site AGROPARC BP 61207 Avignon cedex 09 F84911 France

${ }^{3}$ CNRS, UMR6553 Ecosystèmes Biodiversité Evolution, Campus de Beaulieu Rennes F-35042 France
} 


\section{Introduction}

Extensive grazing (Allen et al. 2011) by large herbivores is a widespread management practice used in protected areas to maintain open habitats and to enhance biodiversity (Van Wieren and Bakker 1998; Rosenthal et al. 2012). The use of natural ecosystems as rangelands by a small number of domestic herbivores is often seen as a suitable response to the disappearance of wild mega-herbivores (Gordon and Duncan 1988; Danell et al. 2006). Regarded as a surrogate of the original interactions between plants and herbivores, domestic grazing would appear to be well suited for the management of natural or semi-natural habitats (Gordon and Duncan 1988; WallisDeVries 1998). However, extensive grazing, that is a long grazing period with low stocking density (Rosenthal et al. 2012), has not always met with the success expected. In particular, it sometimes fails to prevent colonization by woody plants and so to preserve open habitats (Adams 1986; Rambo and Faeth 2001; Mesléard et al. 2011).

The effectiveness of a stocking method may vary according to its intensity, the period of application and the stocking cycle (Savory 1983; Salihi and Norton 1987; Ralphs et al. 1990; Hart and Ashby 1998; Fynn and O'Connor 2000; Dumont et al. 2009). Over the past decades, the potential of short but intensive grazing periods to improve vegetation diversity and to control woody plant dynamics has attracted growing attention in range management (Jeltsch et al. 1997; Todd and Hoffman 1999; Holechek et al. 2000). It has been suggested that mob grazing (grazing at a high stocking density for a short time period, S R M 1998) may be able to control the recruitment and the development of species which would otherwise be neglected by herbivores because of their low nutritional value or palatability (Savory 1988; Perevolotsky and Seligman 1998). Nevertheless, the suitability of using mob grazing depends on the vegetation dynamic (Allen et al. 2011; Briske et al. 2008) and its use in conservation management remains controversial.

\section{Materials and Methods}

Study Site

The study was carried out on the xero-halophytic grasslands of the Tour du Valat estate (Rhône delta, Southern France, $43^{\circ} 29^{\prime} \mathrm{N}, 4^{\circ} 40^{\prime} \mathrm{E}$ ). The Tour du Valat estate, one of the largest in the Camargue (2600 ha), is composed of xero-halophytic grasslands, saline steppes and natural marshes, some of which are kept flooded until summer. The Camargue is characterized by a Mediterranean climate with cold winters and warm dry summers (Heurteaux 1970). Precipitation (570 $\mathrm{mm} \mathrm{year}^{-1}$ )
In the coastal deltaic zones of the northern Mediterranean region, xero-halophytic grasslands managed for economic and/or conservation purposes are subjected to strong colonization by shrubs, principally the native Phillyrea angustifolia (narrow-leaved mock privet) (Saumitou-Laprade et al. 2010). Colonization by $P$. angustifolia is considered a threat to this habitat, impacting its value for livestock and conservation because of the disappearance of characteristic species and wildlife using this habitat (Mesléard et al. 2011). This is particularly the case in the Camargue (Rhône delta), where the strong dynamic of encroachment of this common Mediterranean field colonizer has been attributed to the ineffectiveness of traditional extensive grazing, characterized by low stocking density and a long grazing period (Mesléard et al. 2011).

In this study, we questioned the respective effectiveness of high stocking density for a short period (mob stocking) compared to low instantaneous stocking density for a long period, to control the recruitment of $P$. angustifolia. We hypothesized that for an equal annual stocking rate, mob grazing would result in lower recruitment of new individuals and higher mortality of $P$. angustifolia individuals than stocking applied over a long period. To be considered as a possible stocking method, the absence of negative impact of high instantaneous grazing pressure on herbaceous cover still needs to be demonstrated. We therefore investigated the impact of mob grazing on both $\mathrm{P}$. angustifolia and herbaceous cover. For this purpose, we performed an in situ experiment for 7 years based on three grazing modalities:

(1) a low annual stocking rate of 0.11 native Camargue bulls ha ${ }^{-1}$ year $^{-1}$ applied during 6 months (from October to March), as usually found locally and in existence for roughly three decades (control), (2) a short grazing period (2 days) but with high stocking density (same annual stocking rate as the control),

(3) the cessation of domestic grazing.

occurs mainly during autumn and spring. Xerohalophytic grasslands represent the most diverse habitat of the Rhône delta (Molinier and Tallon 1968) and are a priority habitat (code 6220, European Union Habitats Directive 1992). They are dominated by Brachypodium phoenicoïdes L (thin leaf false brome), but are characterized by a high proportion of annual species including those characteristic of the Mediterranean region, the main ones being: Trifolium scabrum L. (rough clover), Trifolium suffocatum L. (suffocated clover), 
Euphorbia exigua L. (dwarf spurge), Brachypodium distachyon (L.) P. Beauv (purple false brome), Linum strictum L. (flax), Filago pygmaea L. (pygmy cotton rose), Medicago monspeliaca (L.) Trautv. (Montpellier's medick), Catapodium rigidum (L.) C.E. Hubb. (rigid rye-grass, Bensettiti et al. 2005; M.N.H.N 2015). These grasslands face strong colonization by a sclerophyllous shrub $P$. angustifolia (Mesléard et al. 1991). This Oleaceae extends at low altitudes from the Western Mediterranean to Croatia (Pannel and Ojeda 2000) and can locally colonize relatively salty habitats (Mesléard et al. 1991). Its reproduction is favoured by its ornithochorous dispersion (Saumitou-Laprade et al. 2010) and germination of seeds is facilitated by frugivorous birds (Traveset et al. 2008). A survey carried among all the local cattle breeders (200) ranked $P$. angustifolia as one of the most problematic species for rangelands (Mesléard et al. 2015). At the scale of the Tour du Valat estate, over the last decades more than $30 \%$ of grasslands have been transformed to $P$. angustigolia stands (Mesléard et al 2015).

\section{Grazing Treatment}

The experimental design included three treatments (Fig. 1). The first treatment 'L' (Low stocking density) was the original grazing pattern applied over a 180 ha field from October to March (6 months); it corresponds to the control in this study. Over the 7 years of the experiment, the livestock consisted of 50 Camargue bulls, half of them adult animals $(290-350 \mathrm{~kg}$, equivalent to $640-770 \mathrm{lbs}$, about $1 \mathrm{AU}$ ), a quarter 2-year-old calves (180$220 \mathrm{~kg}$, equivalent to $400-490 \mathrm{lbs}$, about $0.6 \mathrm{AU}$ ) and a quarter 1-year-old calves (110-140 kg, equivalent to $240-310 \mathrm{lbs}$, about $0.4 \mathrm{AU})$. This treatment, 'L,' corresponding to an annual stocking rate of $0.11 \mathrm{AU} \mathrm{ha}^{-1}$ year $^{-1}$ (Table 1), had been in place for approximately 20 years. Over the coldest months, marshes are generally not accessible to livestock, but during the growing season and the warmest months (April-May to October), domestic herbivores are generally shifted to the flooded marsh area. The second grazing treatment, ' $\mathrm{H}$ ', (High stocking density), consisted of the same annual stocking rate $\left(0.11 \mathrm{AU} \mathrm{ha}^{-1}\right.$ year $\left.^{-1}\right)$, applied over a very short period of 2 days in early February. February does not correspond to the period when $P$. angustifolia is most palatable, which is later in spring when $P$. angustifolia enters the regrowth stage. Nevertheless, we chose this period for application of the $\mathrm{H}$ treatment because it corresponds to the period of the highest probability for livestock to find water in the channels crossing the rangeland. In addition, a strong disturbance in the $\mathrm{H}$ treatment by trampling or grazing at the time of herbaceous monitoring could have resulted in over-estimation of the grazing impact. The third treatment, ' $\mathrm{N}$ ', consisted in the cessation of domestic grazing through fencing. The experiment started in autumn 2001.

Fig. 1 Experimental design: L low stocking density (50 bulls during 6 months on 180 ha; annual stocking rate $=0,11 \mathrm{AU} \mathrm{ha}^{-1}$ year $^{-1}$ ), $\mathrm{H}$ high stocking density (50 individuals during 2 days on 2 ha; Annual stocking rate $=0,11 \mathrm{AU} \mathrm{ha}^{-1}$ year $\left.^{-1}\right), \mathrm{N}$ no domestic grazing

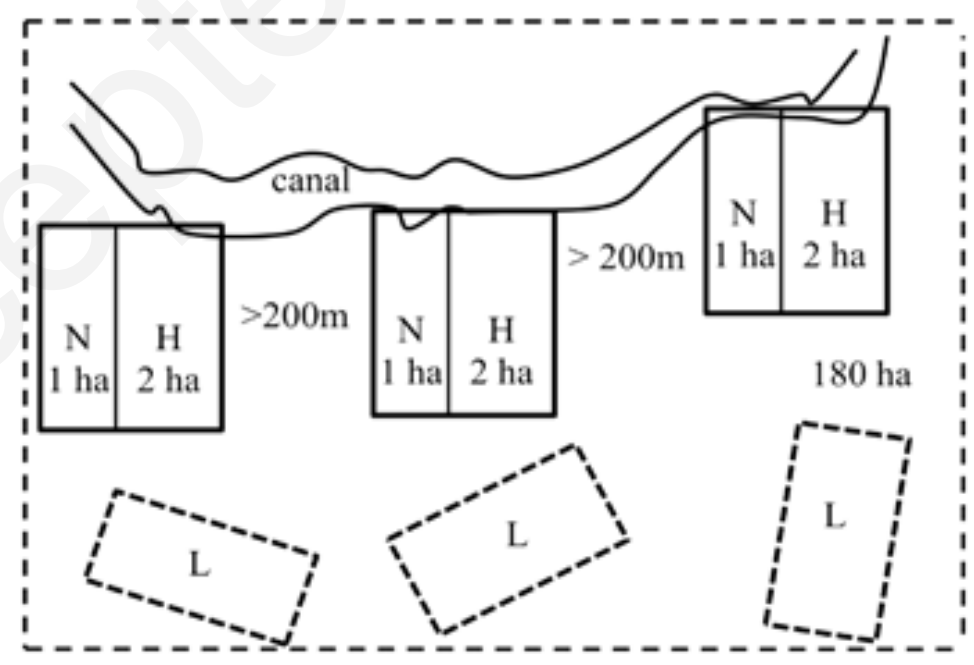


Table 1

Number and class of head, stocking density and annual stocking rate in the treatments L (low stocking density), $\mathrm{H}$ (high stocking density) and $\mathrm{N}$ (no domestic grazing)

\begin{tabular}{|c|c|c|}
\hline Treatment & $\mathbf{L}$ & $\mathbf{H}$ \\
\hline $\begin{array}{l}\text { Number and class of head } \\
\text { (from } 2001 \text { to 2008) }\end{array}$ & $\begin{array}{l}25 \text { mature bulls } 25 \text { young cattle (half } 1 \\
\text { year, half } 2 \text { years old) }\end{array}$ & $\begin{array}{l}25 \text { bulls mature } 25 \text { young cattle (half } 1 \\
\text { year, half } 2 \text { years old) }\end{array}$ \\
\hline Stocking density & $19 \mathrm{AU} \mathrm{ha}^{-1}$, during 2 days & $0,22 \mathrm{AU} \mathrm{ha}^{-1}$, during 180 days \\
\hline Annual stocking rate & 0,11 AU ha $^{-1}$ year-1 & 0,11 AU ha $^{-1}$ year-1 \\
\hline
\end{tabular}

\section{Data Collection}

For the $\mathrm{H}$ and $\mathrm{N}$ treatments, the vegetation survey was conducted in three replicate fenced pastures for each of the two treatments, of respectively two hectares $(\mathrm{H}$ : grazed) and one hectare $(\mathrm{N}$ : ungrazed), placed within about 190 ha of the rangeland $(\mathrm{L}$ treatment), along a canal to enable the domestic herbivores to find water (Fig. 1). $\mathrm{H}$ and $\mathrm{N}$ replicates were placed more than $200 \mathrm{~m}$ apart in order to minimize any possible spatial dependence phenomenon. In the $\mathrm{L}$ treatment, three replicate sites of 2 ha each were chosen at random within the remaining 180 ha, taking care that they were well separated and more than $200 \mathrm{~m}$ away from all the six fenced pastures (Fig. 1).

The number of living and dead individuals of $P$. angustifolia was counted when the experimental treatments were set up in May 2001, and then in May 2008 in order to estimate the recruitment of new individuals during the experiment. The individuals of less than 7 years (i.e. individuals who were established between spring 2001 and spring 2008) were counted separately. When in doubt, the age of individuals was determined by counting the growth rings of the main stem. Counting was conducted along transects of $2.5 \times 10 \mathrm{~m}$ (the same in 2001 and 2008), distributed at random and placed from west to east, with four transects in each of the three replicate sites of the three grazing treatments.

In mid-April 2001 and in mid-April 2008, we monitored herbaceous vegetation in the same five $40 \times 40 \mathrm{~cm}$ permanent quadrats per site, considered as pseudo-replicates, randomly located within each site of the three treatments, checking that quadrats at each site were more than 10 meters apart.

Species frequencies were recorded by the pinpoint method at 36 pinpoints $(3 \mathrm{~cm}$ apart from each other), through a set of two crossing lines in each quadrat (Damgaar et al. 2011). The number of species within the quadrat was recorded. The vegetation structure in each quadrat was described by:

the species richness,

the Shannon diversity index $\mathrm{H}^{\prime}$ (Pielou 1975) where $\mathrm{H}^{\prime}=$

$\sum S i=1 \mathrm{p} i \log 2 \mathrm{p} i \sum \mathrm{i}=1 \mathrm{~S}$ pilog2pi

with $\mathrm{pi}=$ proportion of species $\mathrm{i}$ and $\mathrm{S}=$ total number of species

the evenness $\mathrm{J}^{\prime}=\mathrm{H}^{\prime} / \log _{2} \mathrm{~S}$

the contribution (\% cover) of annual species, the contribution of Mediterranean characteristic annual species.

Analyses

Analyses were performed by Generalized Linear Model using a nested-design analysis of variance (ANOVA). We tested the impact of the three grazing treatments on three parameters related to the $P$. angustifolia population (number of new, old and dead individuals), and five parameters related to the herbaceous vegetation (Species Richness, diversity, evenness, contribution of annual species, contribution of species characteristic of the Mediterranean region). For analyses related to individuals and dead individuals of $P$. angustifolia, pseudo-replicates were nested in sites and all effects (grazing treatment, sites, pseudo-replicates) were nested in time. For the analysis on new individuals of $P$. angustifolia, site and pseudoreplicate effects were nested in grazing treatment. For the analysis of the herbaceous vegetation, pseudo-replicates were nested in grazing treatment and all effects were nested in time. The resulting models show average estimates with their $95 \%$ confidence interval. When a significant difference occurred, we used a post hoc Scheffé test to identify what type of grazing pressure was responsible for the observed difference. All analyses were performed with Statistica version 12.0 (StatSoft Inc.). 


\section{Results}

\section{P. Angustifolia}

Although it explained $10 \%$ of the variance, we did not find a significant time effect on the number of individuals (Table 2). Only 5.5 and $3.6 \%$ of the variance was respectively explained by the factors "site" and "pseudo-replicates", the impact of which was not found significant by the analysis in either case. By contrast, we found a strong treatment effect nested in time on the number of individuals, which explained $80 \%$ of its variance (Table 2). The number of individuals in the $\mathrm{H}$ treatment only significantly differed from the two other treatments in 2008 (Sheffé-test $\mathrm{P}=0.0015$ ). The mean number of individuals (per $25 \mathrm{~m}^{2}$ ) before and at the end of the experiment were, respectively, 3.6 and 5.2, for $\mathrm{L}$ treatment, 4.6 and 5 for $\mathrm{N}$ treatment, 4.4 and 0.7 for $\mathrm{H}$ treatment (Fig. 2). Over the 7 years of experimentation, the average rates of increase of $P$ angustifolia individuals were thus $1.4,1.1$ for $\mathrm{L}$, and $\mathrm{N}$ respectively, and 0.2 for $\mathrm{H}$.

Table 2

Results of the ANOVA ( $\mathrm{F}$ and $\mathrm{P}$ values) as the number of living and death individuals of $\mathrm{P}$ angustifolia as outcome variables and the predictor variables: treatment, site, pseudo-replicates and time

\begin{tabular}{|l|l|l|}
\hline \multicolumn{1}{|c|}{ Factors variables } & \multicolumn{1}{c|}{ Nb of individuals } & \multicolumn{1}{c|}{ Nb of dead individuals } \\
\hline Treatment & $\mathrm{F}(2,180)=11.7 \mathrm{P}=0.000001$ & $\mathrm{~F}(4,44)=30.1 \mathrm{P}<0.000001$ \\
\hline Site (time) & $\mathrm{F}(6,180)=0.8 \mathrm{P}=0.52$ & $\mathrm{~F}(4,44)=0.1 \mathrm{P}=0.98$ \\
\hline Pseud-repl. (Site $\times$ Time) & $\mathrm{F}(9,180)=0.5 \mathrm{P}=0.93$ & $\mathrm{~F}(9,44)=1.0 \mathrm{P}=0.50$ \\
\hline Time & $\mathrm{F}(1,44)=1.6 \mathrm{P}=0.22$ & $\mathrm{~F}(1,44)=34.4 \mathrm{P}=0.00001$ \\
\hline
\end{tabular}

Fig. 2 Number of individuals and numbers of dead individuals per $25 \mathrm{~m}^{2}$ estimated in the three grazing treatments for the years 0 (o) and $+7(\bullet)$ estimated by the GLM procedure (with their 95\% confidence interval). $\mathrm{L}$ low stocking density ( 50 bulls during 6 months on 180 ha; annual stocking rate $=0,11 \mathrm{AU} \mathrm{ha}^{-1} \mathrm{year}^{-1}$ ), $\mathrm{H} \mathrm{high}$ stocking density (50 individuals during 2 days on 2 ha; annual stocking rate $=0,11 \mathrm{AU} \mathrm{ha}^{-1}$ year $^{-1}$ ), $\mathrm{N}$ no domestic grazing. Significant differences are indicated by letters a and $\mathrm{b}$

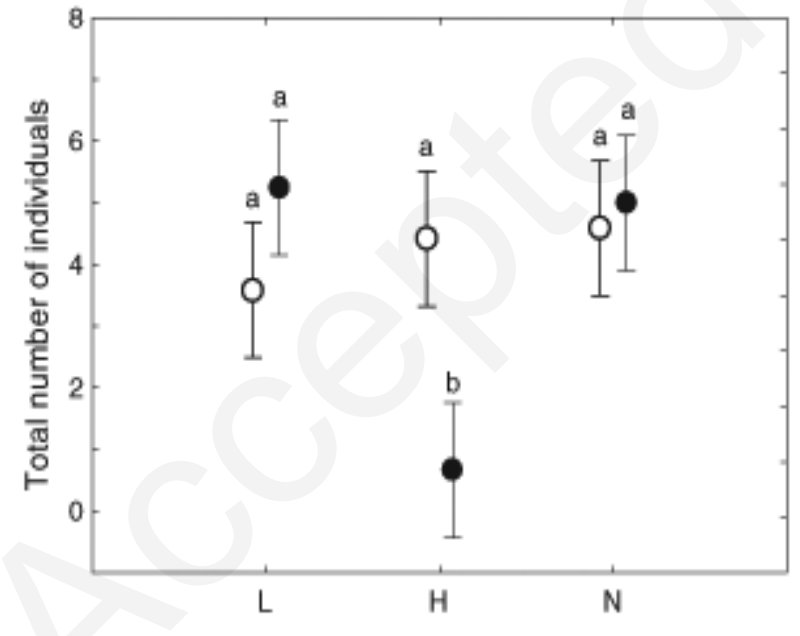

The number of dead individuals did not significantly differ between the three grazing treatments in 2001, but we found a significant difference in the number of dead individuals between years (Table 2), the factor 'time' explaining $52 \%$ of its variance. We also found a significant impact of the grazing treatment, which explained $46 \%$ of the variance. The difference in the number of dead individuals between years was

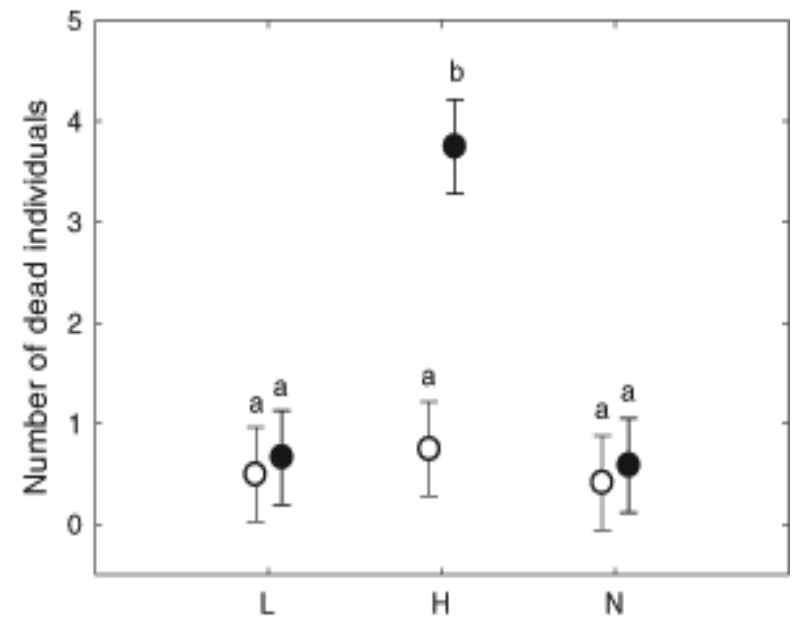

only significant for the $\mathrm{H}$ treatment (Sheffé-test $\mathrm{P}<0.001)$. The estimated number of dead individuals per $25 \mathrm{~m}^{2}$ was $0.5,0.4,0.7$, for $\mathrm{L}, \mathrm{N}$ and $\mathrm{H}$, respectively, in 2001, and $0.7,0.6$ and 3.8, respectively, in 2008 (Fig. 2).

We found a significant impact of the grazing treatment on the number of new individuals, which explained $93.3 \%$ of the variance of this number 
(Table 2). The $\mathrm{H}$ treatment led to a significantly different number of $P$. angustifolia new individuals compared to the $\mathrm{L}$ and $\mathrm{N}$ treatments (Sheffé-test $\mathrm{P}<0.001, \quad \mathrm{P}=0.013$ respectively), while no significant difference was found between treatments $\mathrm{L}$ and $\mathrm{N}$ (Sheffé-test $\mathrm{P}=0.069$ ). The factors 'site' and 'pseudo-replicates' only explained 5 and $1.7 \%$ of the variance of the number of new individuals and were not significant (Table 2). The number of new individuals recruited per $25 \mathrm{~m}^{2}$ estimated by the GLM procedure was $2.4,1.4$ and 0 for L, N and $\mathrm{H}$ treatments, respectively (Fig. 3).

Fig. 3 Number of new individuals per $25 \mathrm{~m}^{2}$ recruited in the three grazing treatments between the years 0 and +7 estimated by the GLM procedure (with their 95\% confidence interval). L low stocking density (50 bulls during 6 months on 180 ha; annual stocking rate $=0,11 \mathrm{AU} \mathrm{ha}^{-1}$ year ${ }^{-1}$ ), $\mathrm{H}$ : high stocking density (50 individuals during 2 days on 2 ha; annual stocking rate $\left.=0,11 \mathrm{AU} \mathrm{ha}^{-1} \mathrm{year}^{-1}\right)$, N: no domestic grazing

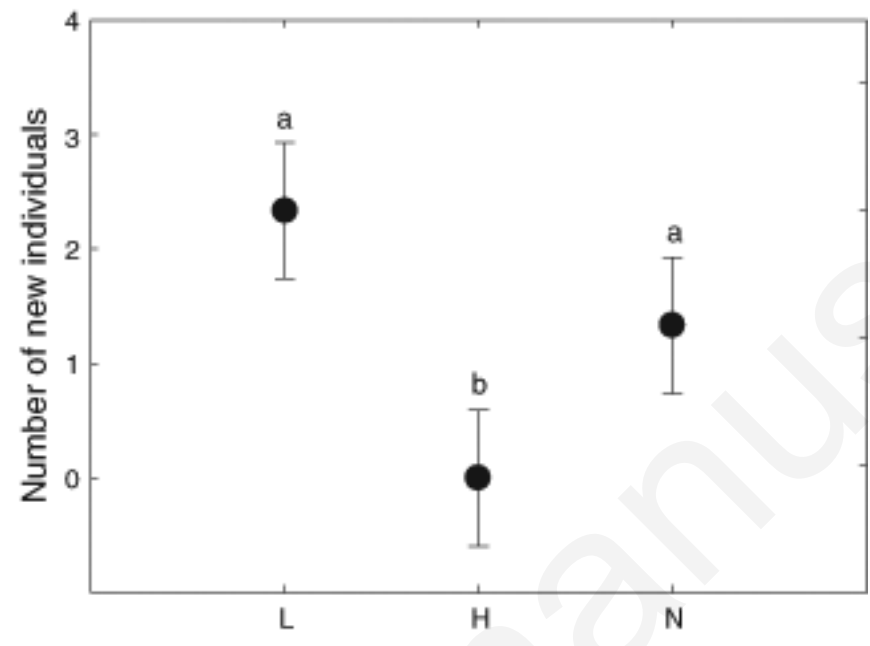

Herbaceous Response

The factors 'time' and 'site' significantly altered the herbaceous species richness (Table 3). They respectively explained 78 and $17 \%$ of the variance of SR. Richness did not differ between the three treatments in 2001 (average of 22.8 species per
$0.8 \mathrm{~m}^{2}$ ), nor between these three SR values in 2001 and those of the $\mathrm{L}$ and $\mathrm{H}$ treatments in 2008. The SR was lower in the $\mathrm{N}$ treatment in 2008 than in 2001 (Sheffé-test $\mathrm{P}=0.034$ ), with 25 and 17.2 species per $0.16 \mathrm{~m}^{2}$, respectively.

Table 3

Results of the ANOVA ( $\mathrm{F}$ and $\mathrm{P}$ values) as the number of new individuals of P. angustifolia as outcome variable and the predictor variables: treatment, site and pseudo-replicates

\begin{tabular}{|l|l|}
\hline \multicolumn{1}{|c|}{ Factors variables } & \multicolumn{1}{c|}{ Nb of new individuals } \\
\hline Treatment & $\mathrm{F}(2,18)=17.1 \mathrm{P}=0.00007$ \\
\hline Site (treatment) & $\mathrm{F}(6,18)=0.9 \mathrm{P}=0.50$ \\
\hline Pseud-repl. (treatment) & $\mathrm{F}(9,18)=0.3 \mathrm{P}=0.96$ \\
\hline
\end{tabular}

The factors 'time' and 'grazing-treatment' significantly altered the Shannon-Weaver index (Table 4). They respectively explained 91 and 6\% of the index variance. The Shannon-Weaver index was lower in the $\mathrm{N}$ treatment in 2008 than in 2001 (Scheffé-test $\mathrm{P}<0.001$ ), but did not differ between the three treatments in 2001 or between those treatments and the $\mathrm{L}$ or $\mathrm{H}$ treatments in 2008. 
Table 4

Results of the ANOVA (F and P values) as the species richness, the Shannon-Weaver index, the evenness, the contribution of annual species, the contribution of the characteristic Mediterranean annual species as outcome variables and the predictor variables: treatment, site, pseudo-replicates and time

\begin{tabular}{|c|c|c|c|c|c|}
\hline $\begin{array}{c}\text { Factors } \\
\text { variables }\end{array}$ & Sp. richness & $\begin{array}{c}\text { Shannon-Weaver } \\
\text { Index }\end{array}$ & Eveness & $\begin{array}{l}\text { Contribution } \\
\text { annual sp. }\end{array}$ & $\begin{array}{l}\text { Contribution. } \\
\text { characat. sp. }\end{array}$ \\
\hline $\begin{array}{l}\text { Treatment } \\
\text { (time) }\end{array}$ & $\begin{array}{l}F(4,56)=0.7 \\
P=0.62\end{array}$ & $\begin{array}{l}F(4,56)=2.9 \\
P=0,03\end{array}$ & $\begin{array}{l}F(4,56)=6.7 \\
P=0.00019\end{array}$ & $\begin{array}{l}F(2,56)=7.7 \\
P=0.00005\end{array}$ & $\begin{array}{l}F(4,56)=5.3 \\
P=0.001\end{array}$ \\
\hline Site (time) & $\begin{array}{l}F(4,56)=3.9 \\
P=0.0078\end{array}$ & $\begin{array}{l}F(4,56)=0.5 \\
P=0.71\end{array}$ & $\begin{array}{l}\mathrm{F}(4,56)=1.2 \\
\mathrm{P}=0.31\end{array}$ & $\begin{array}{l}F(4,56)=2.8 \\
P=0.036\end{array}$ & $\begin{array}{l}F(4,56)=4.4 \\
P=0.0038\end{array}$ \\
\hline $\begin{array}{l}\text { Pseud.-repl. } \\
\text { (Treat. × Tim } \\
\text { e) }\end{array}$ & $\begin{array}{l}F(24,56)=0.4 \\
P=0.99\end{array}$ & $\begin{array}{l}F(24,56)=0.5 \\
P=0.96\end{array}$ & $\begin{array}{l}F(24,56)=1.0 \\
P=0.52\end{array}$ & $\begin{array}{l}\mathrm{F}(24,56)=0.8 \\
\mathrm{P}=0.73\end{array}$ & $\begin{array}{l}\mathrm{F}(24,56)=0.4 \\
\mathrm{P}=0.99\end{array}$ \\
\hline Time & $\begin{array}{l}\mathrm{F}(1, \\
56)=17.4 \mathrm{P}=0.000 \\
11\end{array}$ & $\begin{array}{l}\mathrm{F}(1, \\
56)=39.4 \mathrm{P}<0.000 \\
001\end{array}$ & $\begin{array}{l}\mathrm{F}(9, \\
56)=11.4 \mathrm{P}=0.00 \\
13\end{array}$ & $\begin{array}{l}\mathrm{F}(1, \\
56)=23.0 \mathrm{P}=0.000 \\
01\end{array}$ & $\begin{array}{l}\mathrm{F}(1, \\
56)=2.5 \mathrm{P}=0 \\
11\end{array}$ \\
\hline
\end{tabular}

The factors 'time' and 'grazing-treatment' significantly altered evenness. They respectively explained 56 and $33 \%$ of its variance (Table 3). We found no impact of the factors 'site' or 'pseudo- replicates' on this variable. Evenness was lower in the $\mathrm{N}$ treatment in 2008 than in 2001 (Scheffé-test $\mathrm{P}=0.002$, Fig. 4).

Fig. 4 Evenness and contribution of Mediterranean characteristic annual species in the three grazing treatments for the years 0 (o) and $+7(\bullet)$ estimated by the GLM procedure (with their $95 \%$ confidence interval). L low instantaneous pressure (50 bulls during 6 months on 180 ha; annual stocking rate $=0,11 \mathrm{AU} \mathrm{ha}^{-1}$ year $^{-1}, \mathrm{H}$ : high instantaneous pressure (50 individuals during 2 days on 2 ha; Annual stocking rate $=0,11 \mathrm{AU} \mathrm{ha}^{-1}$ year $^{-1}$ ), $\mathrm{N}$ no domestic grazing. Significant differences are indicated by letters $a$ and $b$

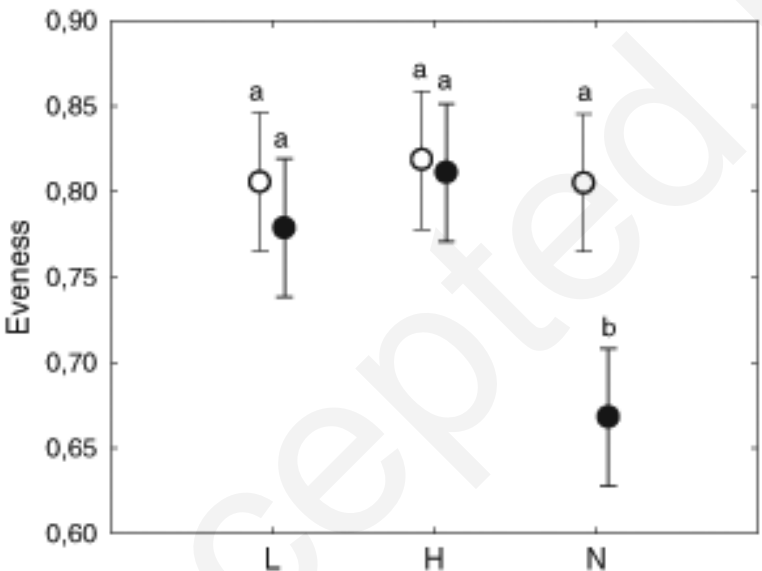

We found a significant impact of the three factors 'time', 'grazing-treatment' and 'site' on the contribution of annual species (Table 4), which respectively contributed 67,22 and $8 \%$ of the variance of this variable. The contribution of annual species did not differ significantly among the three treatments in 2001, or between these three treatments in 2001 and the $\mathrm{L}$ and $\mathrm{H}$ treatments in 2008. It was lower in 2008 than in 2001 in the $\mathrm{N}$ treatment (Scheffé-test $\mathrm{P}<0.001$ ), and lower in the $\mathrm{N}$ treatment than the $\mathrm{L}$ and $\mathrm{H}$ treatments in 2008 (Scheffé-test $\mathrm{P}=0.001, \mathrm{P}=0.002$ respectively).

We found no time effect but a significant impact of grazing-treatment and site on the contribution of

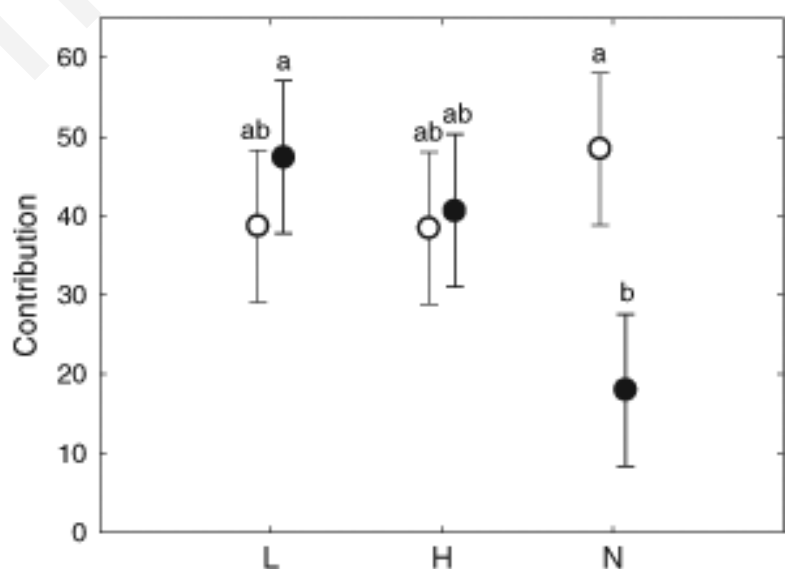

characteristic annual species, which respectively contributed 42 and $35 \%$ of the variance (Table 4). The number of Mediterranean characteristic species was significantly lower in the $\mathrm{N}$ treatment in 2008 than in 2001 (Scheffé-test $\mathrm{P}=0.006$, Fig. 4).

\section{Discussion}

The change of grazing modality strongly altered the mortality and the recruitment of $P$. angustifolia. High stocking density was effective in controlling the recruitment of new individuals and increasing the mortality of this shrub. We did not record a 
lower rate of recruitment in the plots subjected to low stocking density than in the plots without grazing. A previous study (Mesléard et al. 2011) even showed a higher rate of recruitment of $P$. angustifolia in the areas with low stocking density than in the ungrazed areas, where the establishment of new $P$ angustifolia seedlings became negligible after the cessation of grazing due to the development of the herbaceous cover.

Although we made no specific measurements to characterize the mechanisms leading to this impact of $\mathrm{H}$ treatment (high stocking density) on P.angustifolia, the observations made immediately after the departure of livestock showed an impact of trampling mostly on seedling and young individuals, and an impact of grazing mostly on adults. In the L treatment (low stocking density), it has already been demonstrated that the impact of Camargue bulls on seedlings or adults is low (Mesléard et al. 2011). The presence of livestock at high stocking density also led to the immediate mortality of some $P$. angustifolia adults, which can only be explained by physical damage.

Considering only the results on $P$. angustifolia, we are tempted to conclude that mob stocking would help the maintenance of Mediterranean xeric grasslands. The results on the herbaceous community support such a positive conclusion as analyses did not show any differences between the two stocking methods tested in SR, diversity, evenness and contribution of annual characteristic species. In contrast, 7 years without domestic grazing led to a strong decline in the proportion of herbaceous annual species, and consequently a reduction of diversity, evenness and contribution of annual characteristic species. This increase in the cover of perennial species with the cessation of grazing has been reported in many studies (Allen and Mason 1995; Milchunas et al. 1988; Noy-Meir et al. 1989; Peco et al. 2005; Firincioglu et al. 2007; Golodets et al. 2010), and was therefore highly predictable.

Whether grazing should be considered a disturbance has long been debated (Milchunas et al. 1988; Hobbs and Huenneke 1992; Milchunas and Lauenroth 1993). Here, the stocking method consisting in high stocking density, applied during a restricted period of time, fulfills the main criteria of a disturbance (Rykiel 1985) and as such, it had the desired effect on $P$. angustifolia. Yet, as a disturbance, we might also expect high stocking density applied during a restricted period of time to favor species richness, especially of annual species, by the strong control of dominant species and the creation of regeneration niches (Pickett and White 1985; Bullock et al. 1995; Suding and Goldberg 2001). However, 7 years of application of this high stocking density during a restricted period did not lead to major alterations of the herbaceous community parameters. Various reasons could explain the lack of impact observed: (1) a period of grazing unfavorable to change: February, the month when the mob stocking was applied, corresponds to the end of winter or early spring, a period of low plant growth in the northern Mediterranean coastal zone (Perevolotsky and Seligman 1998), which potentially limited the impact on the vegetation cover; (2) the high inertia of the xero-halophytic grasslands, which meant that 7 years was too short a duration to observe significant changes; (3) a scale of observation that was unsuited to taking into account the effects of grazing (Briske et al. 2008); (4) a set of variables chosen to characterize the herbaceous vegetation that was unsuited to describing changes (Noss 1990; Hickman et al. 2004; Fuhlendorf et al. 2006; Jaunatre et al. 2013). However we observed significant changes in terms of Shannon-Weaver index, SR, evenness and proportion of annuals in the plots where domestic grazing was excluded, which suggested that 7 years may be long enough to achieve significant changes in community parameters.

For decades, there has been a consensus on the use of grazing in protected areas where the maintenance of open habitat is a major goal (Olff and Ritchie 1998; Bakker 1989; WallisDeVries et al. 2007). The introduction of a small number of domestic herbivores in continuous stocking can thus be seen as the reestablishment of a natural balance between vegetation and animals (Gordon and Duncan 1988; WallisDeVries 1998). However, one of the aims of grazing used as a management tool is to interrupt the successional dynamic that, without intervention, would cause colonization by woody species and consequently the decrease of herbaceous biodiversity and/or the local disappearance of species targeted by the management strategy. Yet, only high stocking densities can cause the reduction of poorly palatable species by herbivores (Perevolotsky and Seligman 1998; Rutherford and Powrie 2011). Our purpose is not to substitute one kind of dogma for another by rejecting continuous stocking and advocating the sole use of mob stocking. However, when colonization by woody plants is evidently the main and immediate threat, the priority action to be taken is to provide the appropriate means to stop this encroachment, while preserving or enhancing the herbaceous community. In our field experiment, the low annual stocking rate (Dumont et al. 2012), applied in continuous stocking, proved not to be a good method to keep the grassland intact according to the European Directive criteria (European Union Habitats Directive 1992). By contrast, applied in the form of mob grazing before the period of full re-growth, it showed no evidence of negative impact on the herbaceous community but was clearly effective in controlling encroachment by woody species. 
Previous studies conducted in the Rhône delta showed that bulls in semi-free ranging favored the spread of poorly palatable species (Mesléard et al. 2011, 2015). Our results strongly suggest that grazing in the form of concentrated heavy grazing during short periods, by its impact on recruitment and on adult individuals, can help to prevent such colonization and also to restore open habitats.

\section{Conclusion}

In rangeland, the stocking period and stocking rate are generally considered as the most controllable management decisions (Ash and Strafford Smith 1996; Metzger et al. 2005; Briske et al. 2008). However, extensive grazing may correspond to a low annual stocking rate (Rosenthal et al. 2012), in the form of long grazing periods with low stocking density or in the form of short periods with higher stocking density. Thus, as in our example, mob stocking is also a potential management option (Del Pozo et al. 2006). In a context where climatic conditions are not a limiting factor for herbaceous cover development, mob grazing may be used as a stocking method, alternating or not with low grazing pressure, to fulfill particular objectives such as the control of bush encroachment. In this case, the grazing period will have to be chosen not only according to the carrying capacity but also according to the seasonal vulnerability of herbaceous species. The introduction of drastic methods of woody plant control may not be an optimum management strategy for grass and forage consumption; nevertheless, it could be a pivotal medium- or long-term management strategy to conserve characteristic flora, fauna and habitat (Marone and Lill 1985; Osem et al. 2002).

\section{Acknowledgements}

This work was supported by the Fondation Tour du Valat and the Fondation MAVA. We warmly thank the staff of Tour du Valat estate, especially Olivier M. Pineau and volunteers involved in grazing management, for their help.

\section{References}

Adams SN (1986) Sheep performance and tree growth on a grazed Sitka spruce plantation. Scott For 40(4):259-263

Allen RB, Wilson JB, Mason CR (1995) Vegetation change following exclusion of grazing animals in depleted grasslands, Central Otago, New Zealand. J Veg Sci 6(5):615-626

Allen VG, Batello EJ, Berreta EJ, Hodgson J, Kothmann M, Li x, McIvor J, Milne J,
Morris C, Peeters A, Sanderson M (2011) An international terminology for grazing lands and grazing animals. Grass Forage Sci 66:2-28

Ash AJ, Strafford Smith DM (1996) Evaluating stocking rate impacts in rangelands: Animals don't practice what we preach. Rangel J 18:216-243

Bakker JP (1989) Nature management by grazing and cutting: On the ecological significance of grazing and cutting regimes applied to restore former species-rich grassland communities in the Netherlands. Springer, Dordrecht, Geobotany 14

Bailey DW, Dumont B, Wallis DeVries MF (2008) Utilization of heterogeneous grasslands by domestic herbivores: Theory to management. Ann Zootech 47:321-333 Bensettiti F, Boulet V, Chavaudret-Laborie C, Deniaud J (2005) Cahiers d'habitats Natura 2000. Connaissance et gestion des habitats et des espèces d'intérêt communautaire. Tome 4 Habitats agropastoraux. MEDD/MAA PAR/MHN. La documentation Française 2:227-229

Briske DD, Derner JD, Brown JR, Fuhlendorf SD, Teague WR, Havstad KM, Gillen RL, Ash AJ, Willms WD (2008) Rotational grazing on rangelands: Reconciliation and perception and experimental evidence. Rangel Ecol Manage 61:3-17

Bullock JM, Silvertown J, Suttonn M (1995) Gap colonization as a source of grassland community change: Effects of gap size and grazing on the rate and mode of colonization by different species. Oikos 72:273-282

Danell K, Bergstrom R, Duncan P, Pastor J (2006) Large herbivore ecology, ecosystem dynamics and conservation. Cambridge University Press, Cambridge

Del Pozo A, Ovalle C, Casado MA, Acosta B, de Miguel JM (2006) Effects of grazing intensity in grasslands of the Espinal of central Chile. J Veg Sci 17(6):791-798

Damgaar Ch, Merlin A, Mesléard F, Bonis A (2011) The demography of space occupancy: measuring plant colonisation and survival probabilities using repeated pin-point measurements. Methods Ecol Evol 2:110-115

Dumont B, Farrugia A, Garel JP, Bachelard P, Boitier E, Frain M (2009) How does grazing intensity influences the diversity of plants and insects in a species-rich upland grassland on basalt soils. Grass Forage Sci 64:92-105

Dumont B, Rossignol N, Loucougaray G, Carrère P, Chadoeuf J, Fleurance G, Bonis A, Farruggia A, Gaucherand S, Ginane C, 
Louault F, Marion B, Mesléard F, Yavercovski Y (2012) When does grazing generate stable vegetation patterns in temperate pastures? Agric Ecosyt Environ 153:50-56

European Union Habitats Directive (1992) European Union, Brussels. http://ec.europa.eu/environment/nature/legi slation/habitatsdirective/indexen.htm

Firincioglu HK, Seefeldt SS, Sahin B (2007) The effects of long-term grazing exclosures on range plants in the central Anatolian region of Turkey. Environ Manage 39(3):326-337

Fuhlendorf SD, Harrel WC, Engle DM, Hamilton RG, Davis CA, Leslie D (2006) Should heterogeneity be the basis for conservation? Grassland bird response to fire and grazing. Ecol Appl 16:1706-1716

Fynn RWS, O'Connor TG (2000) Effect of stocking rate and rainfall on rangeland dynamics and cattle performance in a semi-arid savanna, South Africa. J Appl Ecol 37:491-507

Golodets C, Kigel J, Sternberg M (2010) Recovery of plant species composition and ecosystem function after cessation of grazing in Mediterranean grasslands. Plant Soil 329(1-2):365-378

Gordon I, Duncan P (1988) Pastures new for conservation. New Sci 117:54-59

Hart RH, Ashby MM (1998) Grazing intensities, vegetation, and heifer gains: 55 years on short grass. J Range Mange 51:393-398

Heurteaux P (1970) Rapports des eaux souterraines avec les sols halomorphes et la végétation en Camargue. La Terre et la Vie 24:467-510

Hickman KR, Harneett DC, Cochran RC, Owensby CE (2004) Grazing management effects on plant species diversity in tall grass prairie. J Range Manage 57:58-65

Hobbs RJ, Huenneke LF (1992) Disturbance, diversity and invasion: implications for conservation. Conserv Biol 6(3):324-333

Holechek JL, Gomes H, Molinar F, Galt D, Valdez R (2000) Short-Duration Grazing: The facts in 1999. Rangelands 22(1):18-22

Jaunatre R, Buisson E, Muller I, Morlon H, Mesléard F, Dutoit T (2013) New synthetic indicators to assess community resilience and restoration success. Ecol Indic 29:468-477

Jeltsch F, Milton SJ, Dean WRJ, Van Rooyen N (1997) Analyzing shrub encroachment in the Southern Kalahari: a grid-based modeling approach. J Appl Ecol 34:14971508

Marone M, Lill A (1985) The influence of livestock grazing and weed invasion on habitat use by birds in grassy woodland remnants. Biol Conserv 124:439-450

Metzger KL, Coughenour MB, Reich RM, Boone RB (2005) Effects of seasonal grazing on plant species diversity and vegetation structure in a semi-arid ecosystem. JArid Environ 61(1):147-160

Mesléard F, Grillas P, Lepart J (1991) Plant community succession in a coastal wetland after abandonment of cultivation: The example of the Rhône delta. Vegetatio 94:35-45

Mesléard F, Mauchamp A, Pineau O, Dutoit T (2011) Rabbits are more effective than cattle for limiting shrub colonization in Mediterranean xero-halophytic meadows. Ecosciences 18(1):37-41

Mesléard F, Yavercovski N, Dutoit T (2015) Photoperiod buffer responses to salt and temperature during germination of to coastal salt-marsh colonizers Juncus acustus and Juncus maritimus. Plant Biosyst. doi:10180/1126.3504.2015.1007898

Milchunas D, Sala OE, Lauenroth WK (1988) A generalized model of the effects of grazing by large herbivores on grasslands community structure. Am Nat 132(1):87106

Milchunas DG, Lauenroth WK (1993) Quantitative effects of grazing on vegetation and soils over a global range of environments. Ecol Monogr 67:327-336

MNHN (2015) [Muséum National d'Histoire Naturelle (2003-2015) Inventaire National du Patrimoine Naturel]. http://inpn.mnhn.fr

Molinier R, Tallon G (1968) Etudes botaniques en Camargue. II vers la forêt en Camargue. La Terre et la Vie 19:3-197

Noss RF (1990) Indicators for monitoring biodiversity: A hierarchical approach. Conserv Biol 4:355-364

Noy-Meir I, Gutman M, Kaplan Y (1989) Responses of Mediterranean grasslands plants to grazing and protection. J Ecology 77(1):290-310

Olff H, Ritchie ME (1998) Effects of herbivores on grasslands plant diversity. Trends Ecol Evol 13(7):261-265

Osem Y, Perevolotsky A, Kigel J (2002) Grazing effect on diversity of annual plant communities in a semi-arid rangeland: interactions with small-scale spatial and temporal variation in primary productivity. J Ecol 90:936-946

Pannel JR, Ojeda F (2000) Patterns of flowering and sex-ratio variation in the Mediterranean shrub Phillyrea angustifolia (Oleaceae): Implications for the 
maintenance of males with hermaphrodites. Ecol Lett 3:495-502

Peco B, de Pablos I, Traba J, Levassor C (2005) The effect of grazing abandonment on species composition and functional traits: the case of dehesa grasslands. Basic Appl Ecol 6(2):175-183

Perevolotsky A, Seligman NG (1998) Degradation of Mediterranean rangeland ecosystems by grazing: inversion of a paradigm. BioScience 48:1007-1017

Pickett STA, White PS (1985) The ecology of natural disturbances and patch dynamics. Academic, New York, NY

Pielou EC (1975) Ecological diversity. Wiley, New York, NY

Ralphs MH, Kothmann MM, Taylor CA (1990) Vegetation response to increased stocking rates in short-duration grazing. J Range Manage 43:104-108

Rambo JL, Faeth SH (2001) Effect of vertebrate grazing on plant and insect community. Conserv Biol 13(5):1047-1054

Rosenthal G, Schrautzer J, Carsten E (2012) Lowintensity grazing with domestic herbivores: a tool for maintaining and restoring plant diversity in temperate Europe. Tuexenia 32:167-205

Rutherford MC, Powrie LW (2011) Can heavy grazing on communal land elevate plant species richness levels in the Grass land Biome of South Africa. Plant Ecol 212:1407-1418

Rykiel EJ (1985) Toward a definition of ecological disturbance. Aust J Ecol 10:361-365

Salihi DO, Norton BE (1987) Survival of perennial grass seedlings under intensive grazing in semi-arid rangelands. J Appl Ecol 24:145-151

Saumitou-Laprade P, Vernet P, Vassiliasi C, Hoareau Y, DeMagny G, Dommee B, Lepart J (2010) A self-incompatibility systems explains high male frequencies in an androdiocious plant. Science 327:16481650

Savory A (1983) The savory grazing method or holistic resource management. Rangelands 5:155-159

Savory A (1988) Holistic resource management. Island Press, Covelo, CA

S R M (1998) Glossary of terms used in range management, 4th edn. Society for Range Management. https://globalrangelands.org/glossary?

Suding KN, Goldberg D (2001) Do disturbances alter competitive hierarchies? Mechanisms of change following gap creation. Ecology 82(2):2133-2149
Todd SW, Hoffman MT (1999) A fence-line contrast reveal effects of heavy grazing on plant diversity and community composition in Namaqualand, South Africa. Plant Ecol 142:169-178

Traveset A, Rodríguez-Pérez J, Pías B (2008) Seed trait changes in dispersers' gut and consequences for germination and seedling growth. Ecology 89:95-106

Van Wieren SE, Bakker JP (1998) Grazing for conservation in the 21 st century. In: Wallis DeVries MF, Bakker JP, Van Weiren SE (eds) Grazing and conservation management. conservation biology series 11. Kluwer Academic, Dordrecht, p 349363

WallisDeVries MF (1998) Large herbivores as key factors for nature conservation. In: Wallis DeVries MF, Bakker JP, Van Weiren SE (eds) Grazing and conservation management. conservation biology series 11. Kluwer Academic, Dordrecht, p 1-20

WallisDeVries MF, Parkinson AE, Dulphy JP, Sayer M, Diana E (2007) Effects of livestock breed and grazing intensity on biodiversity and production in grazing systems. Grass Forage Sci 62:185-197 